\title{
Correction to: A review of the genome, epidemiology, clinical features, prevention, and treatment scenario of COVID-19: Bangladesh aspects
}

\author{
Abdullah Al Noman ${ }^{1}$, Md. Shofiqul Islam', Samiron Sana ${ }^{2,3^{*}}$, Prapti Mondal ${ }^{4}$, Rima Islam Meem', Sohel Rana ${ }^{3}$,
} Debashish Mondol ${ }^{3}$, Manoshi Sana ${ }^{5}$, Sheikh I. Hossain ${ }^{6}$, Taufique Joarder ${ }^{7}$ and Kishor Mazumder ${ }^{3,8}$

\section{Correction to: Egypt J Bronchol (2021) 15:8 \\ https://doi.org/10.1186/s43168-021-00053-2}

After publication of the original article [1], the authors identified an error in the author's name of Sohel Rana.

The incorrect author name is: Shohel Rana.

The correct author name is: Sohel Rana.

The original article has been corrected.

\begin{abstract}
Author details
'Department of Genetic Engineering \& Biotechnology, Faculty of Biological Science and Technology, Jashore University of Science and Technology, Jashore 7408, Bangladesh. ${ }^{2}$ Pharmacy Discipline, Life Science School, Khulna University, Khulna 9208, Bangladesh. ${ }^{3}$ Department of Pharmacy, Faculty of Biological Science and Technology, Jashore University of Science and Technology, Jashore 7408, Bangladesh. ${ }^{4}$ Department of Zoology, Rajshahi College, Rajshahi 6100, Bangladesh. ${ }^{5}$ Dhaka Medical College, Dhaka 1000, Bangladesh. ${ }^{6}$ School of Mechanical and Mechatronic Engineering, University of Technology Sydney, 81 Broadway, Ultimo, NSW 2007, Australia. ${ }^{7}$ Public Health Foundation, Dhaka, Bangladesh. ${ }^{8}$ School of Biomedical Sciences, Charles Sturt University, Wagga, NSW 2678, Australia.
\end{abstract}

Published online: 08 February 2021

\section{Reference}

1. Al Noman A et al (2021) A review of the genome, epidemiology, clinical features, prevention, and treatment scenario of COVID-19: Bangladesh aspects. Egypt J Bronchol 15:8. https://doi.org/10.1186/s43168-021-00053-2

\footnotetext{
The original article can be found online at https://doi.org/10.1186/s43168021-00053-2.

* Correspondence: samironsana@gmail.com; ms191116@ku.ac.bd

${ }^{2}$ Pharmacy Discipline, Life Science School, Khulna University, Khulna 9208, Bangladesh

${ }^{3}$ Department of Pharmacy, Faculty of Biological Science and Technology, Jashore University of Science and Technology, Jashore 7408, Bangladesh Full list of author information is available at the end of the article
}

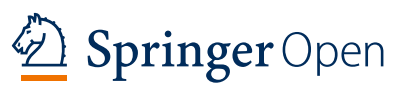

() The Author(s). 2021 Open Access This article is licensed under a Creative Commons Attribution 4.0 International License, which permits use, sharing, adaptation, distribution and reproduction in any medium or format, as long as you give appropriate credit to the original author(s) and the source, provide a link to the Creative Commons licence, and indicate if changes were made. The images or other third party material in this article are included in the article's Creative Commons licence, unless indicated otherwise in a credit line to the material. If material is not included in the article's Creative Commons licence and your intended use is not permitted by statutory regulation or exceeds the permitted use, you will need to obtain permission directly from the copyright holder. To view a copy of this licence, visit http://creativecommons.org/licenses/by/4.0/. 